\title{
Hans Peter Cornelius (1888-1950): a perfect mapping geologist and scientific explorer of the Alps
}

\author{
Wolf-Christian Dullo ${ }^{1}$ [ $\cdot$ Fritz A. Pfaffl ${ }^{2}$
}

Received: 9 February 2020 / Accepted: 22 June 2020 / Published online: 6 July 2020

(c) The Author(s) 2020

\begin{abstract}
Hans Peter Cornelius was a squeamishly and accurately mapping field geologist with an eye for the finest detail as well as for the large-scale architectural structure of mountain ranges. His excellent work concerned the Rhaetian and Allgäu Alps, South Tyrol, the Valais and Ticino in Switzerland and many regions in Austria. His publications on the Err-Julier Group, the Insubric Line, the Großglockner Group, the Rax-Schneeberg Group, the alpine Grauwackenzone, and the Penninic series of the Western and Eastern Alps became particularly important.
\end{abstract}

Keywords Alps $\cdot$ Mapping $\cdot$ Profiles $\cdot$ Tectonics $\cdot$ Regional geology

\section{Introduction}

Hans Peter Cornelius spent most of his life in the field by mapping and drawing the geology he observed. He was outstandingly talented and on top extremely well trained and educated in field observation and documentation. Presentday BSc and MSc modules lack that training quality unfortunately. Cornelius worked in all parts of the Alpine arc and was probably one of the best experts in the Eastern and Western Alps at the time. When asked why he did not start a career as university professor due to his great and comprehensive knowledge, he replied that he would have lost too much time for doing field work (Clar 1951: 85). His first scientific work began in Graubünden, a region to which he remained faithful throughout his life. After completing his doctoral thesis, the Swiss Geological Commission commissioned him to map in southern Graubünden until 1928. The extensive field work culminated in the monographic publications of the Err-Julier Group (Cornelius, 1932, 1935a, 1950a, 1951). With the same intent, he devoted himself to the complex history and structure of the Paleozoic Grauwackenzone in Austria as well as the evolution and the tectonic

Wolf-Christian Dullo

cdullo@geomar.de

1 GEOMAR Helmholtz Zentrum für Ozeanforschung, Wischhofstr. 1-3, 24148 Kiel, Germany

2 Zwiesel, Germany construction of the Tauern window. The Italian Prof. Giorgio Dal Piaz (1872-1962) won him and his wife to map the Italian Dolomites. As leading member of staff of the Austrian Geological Survey (Geologische Bundesanstalt) in Vienna, he mapped the sheets Mürzzuschlag, Kitzbühel-Zell am See, Neunkirchen, and Großglockner. Together with Eberhard Clar (1904-1995), he published the geology of the Grossglockner area (1939), including an excellent geological map on a scale of 1: 25,000 in unbelievably outstanding detail. In addition to these stratigraphic and tectonic works, which are completely listed in Kühn (1952: 255 ff), Cornelius also addressed mineralogical and glacial-morphological issues, such as an alpine occurrence of Sapphirin (1916), new lazulith findings in the Mürz Valley (1931), on the condition of the interglacial rubble covering the Alps (1941a) or on the geology of the Riebeckite gneisses in the Grauwackenzone of the Semmering area (1950b).

In his obituary, Kühn characterized him with the words (1952: 254): "Another reason for his outstanding importance for the Alpine geology was his unique, thorough knowledge of the different parts of the Alps. He had worked in the Western, Southern and Eastern Alps, in the crystalline complex, the Grauwackenzone, the Northern Calcareous Alps, the flysch and molasse zones and he had an experience that an occasional, however, sharp observer could never acquire. Cornelius was the first and, as is to be feared due to the disfavor of the time and due to the lack of a real idealism today, also the last representative of a discipline, which opposes ingenious interpretations, more based on overview 
inspections and strongly based on intuition, as it is certainly necessary in modern geology, by a painstaking elaboration of every single but real existing mountain range in the reconstruction of the Alps".

\section{Biography}

Hans Peter Cornelius was born on September 29th 1888 in Munich, as son of the great philosopher and professor (chair) Hans Cornelius (1863-1947). He inherited the second baptismal name from his grandfather, a famous composer (1824-1874). Hans Peter initially received private school lessons from his parents and only attended public school when he was 13-years-old. As a highly talented and mature youngster, he enrolled at the university in his hometown at the age of 17. From 1905 to 1910, he studied at the universities of Munich, Zurich and Freiburg (Breisgau). In Munich, he was introduced to Alpine geology and petrography by the professors Friedrich August Rothpletz (1853-1918) and Ernst Weinschenk (1865-1921). In 1912, he received his doctorate at the University of Zurich with a thesis on "Petrographic Investigations in the Mountains between the Septimer and Julier Pass (Cornelius 1912) supervised by Ulrich Grubenmann (1850-1924) professor for petrography. He stayed as assistant with Grubenmann until 1913, when he moved to the Geological Commission of the Swiss Society for Science. During the First World War, he was a soldier, then a military geologist. After the war, he worked simultaneously in the Northern Limestone Alps and in the Grauwackenzone as well as in the crystalline of the Central Alps. Already with his dissertation, he paved the road for his extensive Alpine work later on and he correctly can be called as one of the leading Alpine geologists of his time.

In 1928, he started to work as an employee of the Geological Survey in Vienna and in 1937 as a scientific assistant. From 1938 to June 1945, Cornelius held the position as a district geologist at the newly named Reichsanstalt für Bodenforschung Branch Vienna. He became an honorary member of the Natural Research Society in Graubünden (Switzerland) and in 1941, the Academy of Sciences in Vienna appointed him as a corresponding member. Cornelius was an active member of the national socialist party and when the war ended in 1945, he was impeached resulting in his salary deprivation and in an imprisonment, which, was rescinded little later after a lawsuit with acquittal due to the lack of evidence. However, he was not more re-appointed as a member of the Geologische Bundesanstalt. Persecution and detention hit him hard and he suffered a lot (Kühn 1952). On April 2nd 1950, Dr. Hans Peter Cornelius died from heart failure at night during the mapping work in the Höllental, an incisive valley within the Rax Maountains. $\mathrm{He}$ is buried nearby in Nasswald (Lower Austria) in the cemetery for mountaineers. Since 1921, he was married to the Viennese geologist and stratigrapher Dr. Marta Furlani (1886-1974), the first woman in Austria who received a doctoral degree in geosciences (1910). Together with her, he conducted and published many field studies (e.g., Cornelius and Cornelius-Furlani 1925). Posthumously, she published his summarizing work "Grundzüge der Allgemeine Geologie" in Cornelius (1953) by Springer-Verlag in Vienna (Cadisch 1950) (Fig. 1).

It is not the aim of this paper to give a comprehensive appreciation of Cornelius' work, but rather to show how Cornelius created the basic principles through his exact, actually almost pedantic, meticulous field recordings that are still used today in the spatial distribution and arrangement of the lithologies. His keen observations in the field can be found in his detailed, almost print-ready sketches. An early proof of this ability are his staggered cross-sections (Fig. 2), which were published in one of his early papers "Stratigraphy and Tectonics of the Sedimentary Zone of Samaden" (1914: Plate 1) or in the Monograph on the Geology of the Err-Julier Group (1935a, 1950a). These meticulous reconstructions by Cornelius were appreciated in the revision of the Zone of Samaden by Handy et al. (1993) and Handy

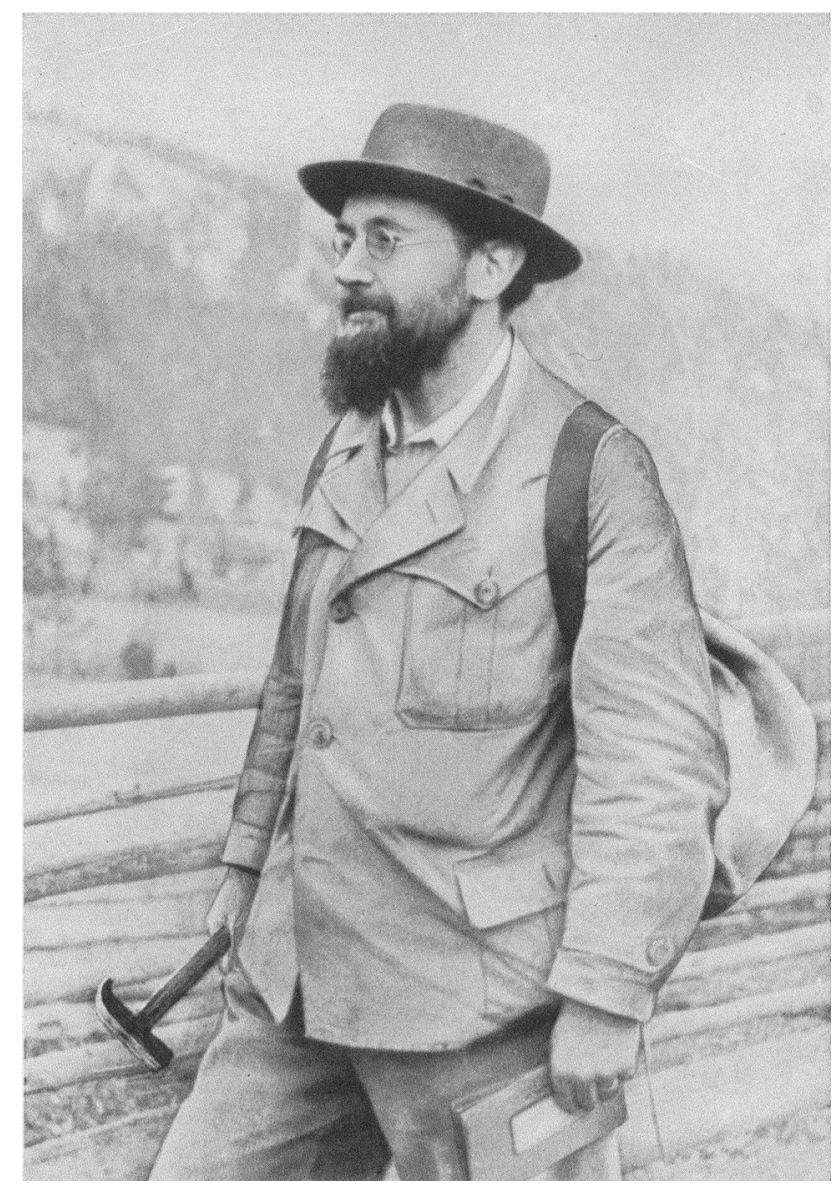

Fig. 1 Dr. H. P. Cornelius (1888-1950), aus Kühn (1952) 


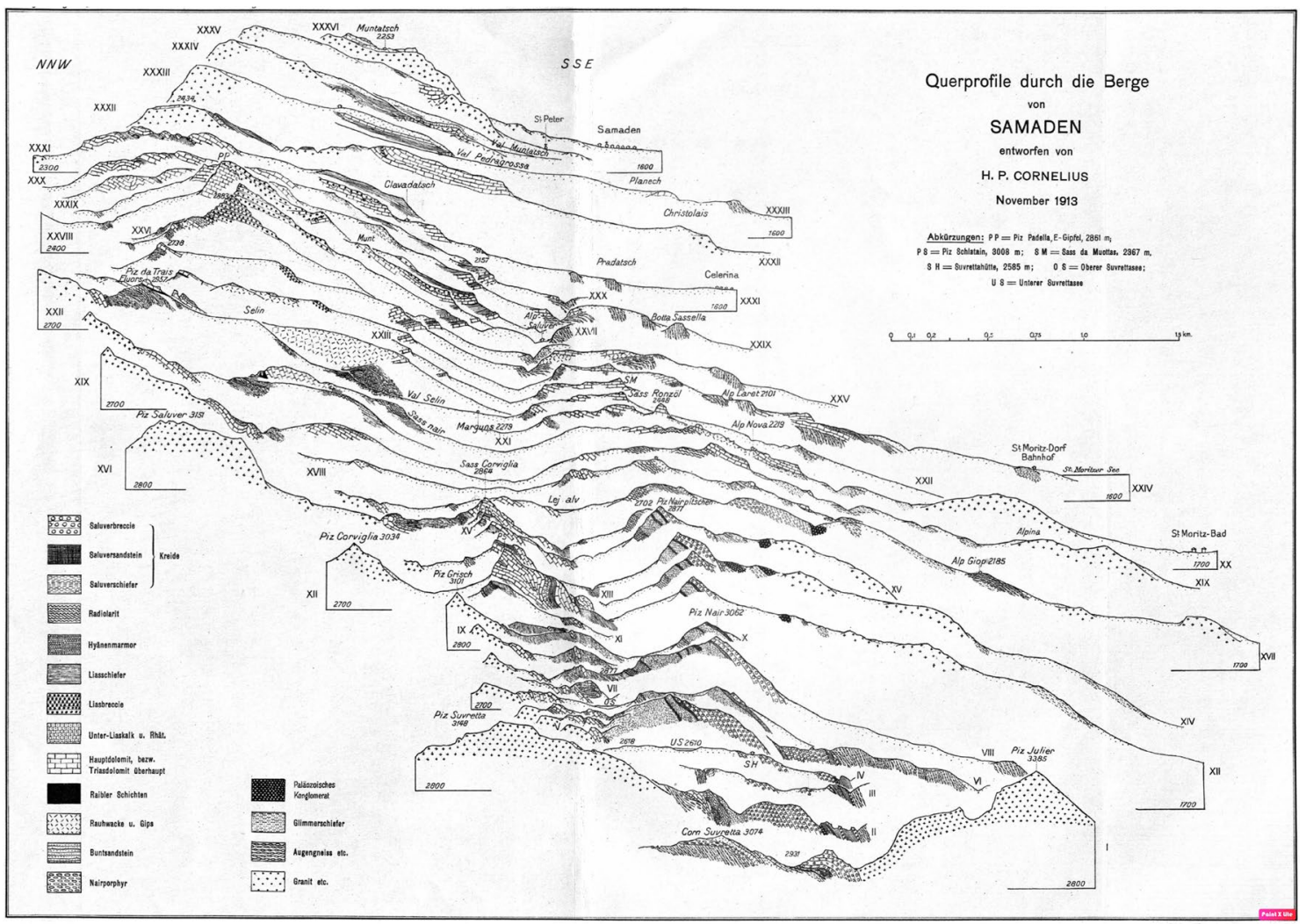

Fig. 2 Cross-sections through the Zone of Samaden drawn in Nov. 1913. From Cornelius (1914)

(1996). Based on our own field observations in the Grauwackenzone, in the Glockner area or in the area of the ErrJulier nappes with their sedimentary cover, we have to state respectfully that Cornelius has not overlooked anything in lithology, even in those areas, extremely difficult to accesshe must have been a bold mountain climber-but also he did not interpret anything that is not there. Nevertheless, there have been changes in the stratigraphic assignment of some of the lithologies he observed, as in the Zone of Samaden (Rössli 1944; Handy 1996).

\section{Exemplary excerpts from his work}

In his comprising paper on the "View of the Eastern Alps in the Sense of the Nappe Theory", there is right at the beginning a description of the concept of nappes (1950c: 273): "It was a source of many misunderstandings that the western alpine geologists have so often emphasized the origin of the nappes from horizontal folds. The opponents then looked for an overturned middle fold limb, which they understandably did not find and concluded that there were no nappes! It would have been clear in Heim's mechanism, however, how an exaggeration of a horizontal fold caused thrusting by disruption and rolling of the middle fold limb and therefore a fully developed middle fold limb should not generally be expected at all and its complete absence should not speak against the origin from a horizontal fold. ..... In these circumstances, it seems best to dispense the genetic model when defining the nappe and to phrase it as such: a nappe is an uniformly moving lamella of the earth's skin, and it will be good to include a minimal thrusting distance (to be determined by convention) in the definition. It is suggested that this is $5 \mathrm{~km}$, what is less should no longer be called nappe". This shows Cornelius' approach in which he does not obscure his observation achieved in the field by a "common" theory and that he prefers to stick to a definition that is reduced to a pure description, although this definition did not terminate the debate about formation of nappes (Tollmann 1973).

Eberhard Clar (1904-1995) his companion in the field during joint mapping activities around the Großglockner remarked to the point (1951: 85/86): "He was averse to theoretical speculations and premature generalizations without an adequate basis of field data and also knew how to evaluate and exploit the work of others with respect for intuitive ideas from this point of view. Accordingly, his maps are kept as free as possible from interpretations derived from the spirit of the time and, in the extent of field-geological possible distinctions, go to the limit of the presentation with respect to scale. However, he never remained stuck in details and 

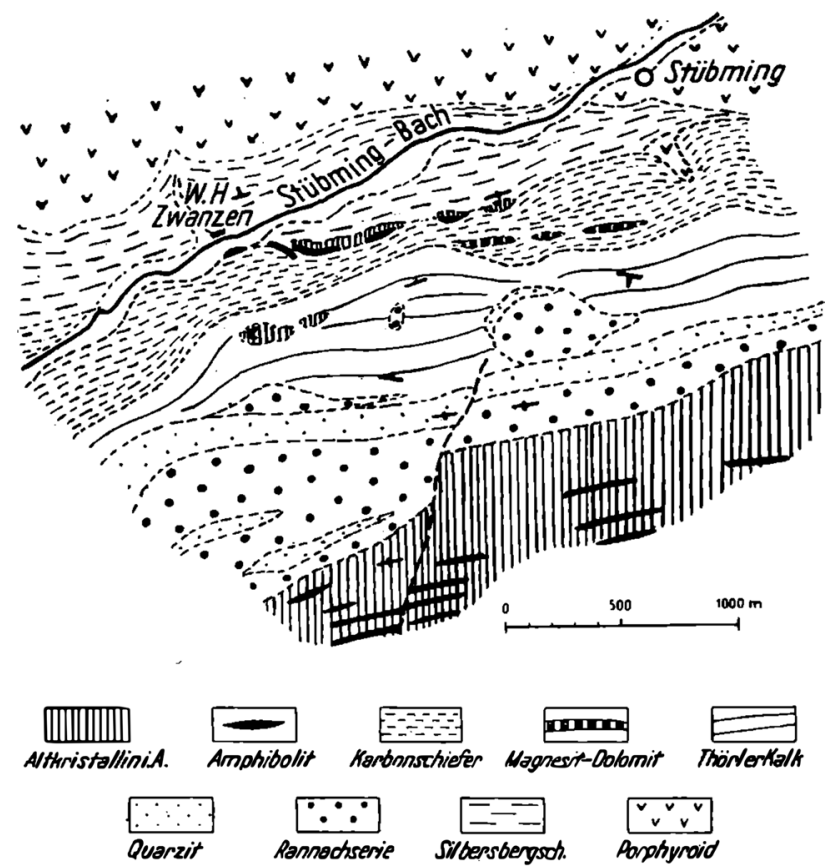

Fig. 3 Geological map of the Stübminggraben

one was amazed during joint investigations by the vision with which Cornelius immediately surveyed the importance of any individual outcrop and observed it with regard to the overall question. Nevertheless, he studied insignificant details with the same interest, and therefore perhaps he precisely recognized what so often had been overlooked by his predecessors".

An example of this style to work in the field is given by Cornelius' first description of various outcrops of "Altkristallin" (=Variscan basement) in the Grauwackenzone like that from the Stübminggraben near Turnau (1941b: 40): "The outcrops (Figs. 3 and 4) occur about 4 km eastnortheast of Turnau, on the southern side of the road that leads through the Stübminggraben and over the Pretalsattel to Veitsch. There is a house just opposite to the Zwanzenhof

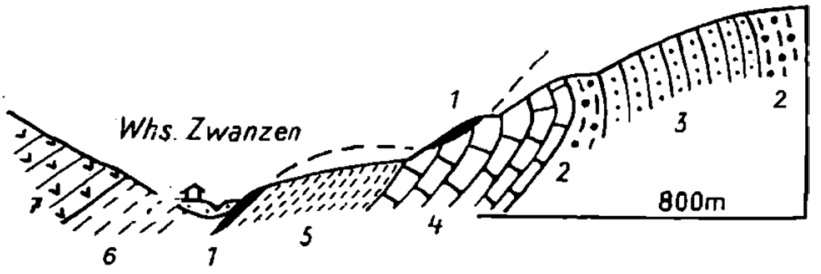

Fig. 4 Section in the upper Stübminggraben. 1 mica schist und retrograde metamorphic rocks, 2 Rannachkonglomerat, 3 quartzite, 4 Törler limestone, 5 Upper Carboniferous schists, 6 Silbersgergseries, 7 porphyry
Inn, and immediately to the west of it there is a cellar built into the slope of the mountain; and at the entrance there is an intensely deformed amphibolite steeply inclined to the $\mathrm{S}$, while a few steps further there are Carboniferous schists on the slope, which apparently overlay the amphibolite directly towards S. A little further to the east there is a small ditch coming from S: here horizontally bedded black Carboniferous schists occur insitu, above there is a small artificial outcrop exhibiting green schists, about 3-4 m, gently inclined to the SW. Both lithologies repeatedly occur on a steep track that leads uphill towards SE; the inclination is now gentle towards N. On top again Carboniferous schists until into the forest; here suddenly steeply SW inclined amphibolite and strongly diaphthoritic paragneiss to mica schists are present. Their strike continues to turn towards W-E and ENE, at the same time the layering gets flatter inclined to the $S$; the amphibolite reaches $2-3 \mathrm{~m}$ (below the path), the paragneiss partly banded by pegmatitic layers below it reaches $6-8 \mathrm{~m}$. The Carboniferous schists above continue; the underlying lithology is made of light gray sericite schists, representing the Silbersberg series here (the normal nappe sequence of the Grauwackenzone is overturned locally!)". An apparent small-scale observation, however, with a larger implication for the geodynamic development of the Grauwackenzone, since the origin of these Altkristallin slabs was discussed controversially. Only detailed observation, sketching and mapping is the solid base for resolving geological problems.

In session report 159 of the Austrian Academy of Sciences (Vienna 1950d: 281), Cornelius presented a summary of the paleogeography and tectonics of the Alpine Paleozoic: "The Grauwackenzone of the area mentioned, between the Aflenz basin and the edge of the Alps, is known to consist of two first-order nappes separated by the "Noric thrust" that can be traced from the area from Liezen (Ennstal) to Gloggnitz. Analogously, I call the upper nappe the Noric nappe; it is again divided into a number of subdivisions, which cannot be dealt with here. I call the lower one after a mining and stratigraphically important location the Veitsch nappe."

The age of this thrust is presumed to be alpine by Cornelius (1952: 213) on the basis of his detailed observations in the field": is the Noric thrust part of the Alpine or of the Variscan folding era? During my field activity, I had always been inclined to consider it Alpidic: it seems to be so nicely connected parallel to the Alpidic nappe tracks of the Semmering area that this is probably the most obvious case; and in the cellular dolomite of the uppermost Massinggraben I thought I had found a Triassic member that had been over thrusted and that, like the Triassic gypsum from Mitterberg near Aflenz (Spengler 1921), would ensure a post Triassic and therefore an Alpidic age". However, he questions this presumption by comparing published observations and continues: "Gaertner 1934, p. 254, and Haberfelner 1935, p. 26, decidedly pointed out that the Noric thrust in the Enns 
Valley is covered by Triassic limestones without continuing in a corresponding thrusting plane within the Limestone Alps; they then consider them Variscan. This is indeed a very strong argument". Today an Alpidic age of the Noric thrust is considered to be certain (Prey 1978; Nievoll 1984), although variscan structural elements are present. Cornelius, therefore, drew the correct conclusion based on his own precise field observations, but was dissuaded by observations by others. Like a legacy, a closing word from one of his last papers may be cited (Cornelius 1950c: 307): "To err is human. That is why no one is blamed for the mistake he made in good faith. Rather, it is the courage of thosewherever they came from-who cleared the way for a first unlikely truth".

The vision and broad regional overview cited by Clar confirm Cornelius' words about the Tauern window (1950c: 280f): "The Tauern window is not only the basic point, but also the pivotal point of the nappe theory in the Eastern Alps... The fact, however, that the concept of the window still has its justification is demonstrated by (among other things): the frequently mentioned analogy of the "Upper Schist Cover" to the western Alpine schistes lustrés. Today, it is no longer limited to calcareous mica schists, serpentine, and prasinite; but also to all different kind of rarer rock types (Cornelius 1933, 1934, 1935b) which occur on both sides in the same way: Eklogites or their derivatives (whereby here as well as there the application of conventional eclogite hypotheses has the same difficulties; see Cornelius and Clar 1939: 16 et seqq), garnet muscovite schists which are rarely more than a few meters thick-which is why they were usually overlooked earlier!-accompanying the contacts of the prasinite with the calcareous mica schists; fine breccias made of phyllitic material within the calcareous mica schists and "spotted schists". The correspondences are such that one can no longer speak of two convergent series; it is a uniform series from Savoy to Katschberg". Cornelius expresses open criticism of the lack of understanding for this comparison and continues: "That the Eastern Alpine geologists are still partially reluctant to recognize this fact-this is only due to the lack of their own views". This sentence is supplemented by the following footnote: "Of course, first of all one has to compare areas that really correspond in terms of series inventory and metamorphosis. In both respects e.g., the frequently cited Prättigau is unsuitable, the schists of which are probably for the most part younger than the Tauern calcareous mica schists. To find their equivalents in striking direction, one has to go much further to the $\mathrm{S}$ - the Penninic Zone is also part of the Alpine bend! On the eastern edge of the Alps, the Avers-Bergell-Malenco area comes into consideration. However, as far as my experience allows, the most perfect correspondence is seen in Zermatt-AostaVanoise: and it is perhaps not a coincidence that from the latter Termier has just come to visit the Tauern".
Acknowledgements Open Access funding provided by Projekt DEAL. We appreciate the support of Mrs. Heidi Düpow from GEOMAR and the librarians of the Deutsche Museum Munich, of the Bayerische Staatsbibliothek Munich, and of the Geological Survey of Vienna in organizing the original papers from Cornelius. We are indebted to Prof. Dr. Richard Lein for his review and his valuable hints. And to Dr. Sascha Flögel for his critical reading and the handling of the manuscript.

Open Access This article is licensed under a Creative Commons Attribution 4.0 International License, which permits use, sharing, adaptation, distribution and reproduction in any medium or format, as long as you give appropriate credit to the original author(s) and the source, provide a link to the Creative Commons licence, and indicate if changes were made. The images or other third party material in this article are included in the article's Creative Commons licence, unless indicated otherwise in a credit line to the material. If material is not included in the article's Creative Commons licence and your intended use is not permitted by statutory regulation or exceeds the permitted use, you will need to obtain permission directly from the copyright holder. To view a copy of this licence, visit http://creativecommons.org/licenses/by/4.0/.

\section{References}

Cadisch J (1950) Nachruf auf Hans Peter Cornelius 1888-1950. Verh Schweiz Naturforsch Ges 130:392-396

Clar E (1951) Nachruf für Hans Peter Cornelius (1888-1950). Verh Geol BA 1951:84-94

Cornelius HP (1912) Petrographische Untersuchungen in den Bergen zwischen Septimer- und Julierpass. Inaug Diss Neues Jahrb Miner 35:374-498

Cornelius HP (1914) Über die Stratigraphie und Tektonik der sedimentären Zone von Samaden. Beitr Geol Karte Schweiz NF XLV:11-43

Cornelius HP (1916) Ein alpines Vorkommen von Sapphirin. Centralbl Mineralogie Geologie und Paläontologie Jahrgang 1916:265-269

Cornelius HP (1931) Neue Lazulithfunde im Mürztal. Verh Geol Bundesanst 1931:93-94

Cornelius HP (1932) Geologische Karte der Err-Julier-Gruppe 1:25000. Schweiz geol Komm Spezialkarte A 115

Cornelius HP (1933) Über einige seltene Gesteinstypen aus dem Grünsteingebiet von Zermatt. Mitt Geol Ges Wien 26:158

Cornelius HP (1934) Das Profil des Col Lauzon in den Grajischen Alpen. Mitt Geol Ges Wien 27:132

Cornelius HP (1935a) Geologie der Err-Julier-Gruppe: 1. Das Baumaterial. Beitr Geol Karte Schweiz NF 70(1):1-321

Cornelius HP (1935b) Profile aus der oberen Val Tournanche. Mitt Geol Ges Wien 28:103

Cornelius HP (1941a) Über die Bedingtheit der interglazialen Schuttumhüllung der Alpen. Ber Reichst f Bodenf Zweigst Wien 169-179

Cornelius HP (1941b) Die Vorkommen altkristalliner Gesteine im Ostabschnitt der nordalpinen Grauwackenzone (zwischen Ternitz und Turnau). Mitt RA Zweigst Wien 2:19-52

Cornelius HP (1950a) Geologie der Err-Julier-Gruppe: 2. Der Gebirgsbau. Beitr Geol Karte Schweiz NF 70(2):1-264

Cornelius HP (1950b) Geologie der Riebeckitgneise in der Grauwackenzone des Semmeringgebietes. Tschermaks Min Pet Mitt 2:24-26

Cornelius HP (1950c) Zur Auffassung der Ostalpen im Sinne der Deckenlehre. ZDDG 92:271-311

Cornelius HP (1950d) Zur Paläographie und Tektonik des alpinen Paläozoikums. Sitzb Akad Wissensch Wien 159:281-290 
Cornelius HP (1951) Geologie der Err-Julier-gruppe: 3. Quartär und oberflächengestaltung hydrologie. Beitr Geol Karte Schweiz NF 70(3): $1-75$

Cornelius HP (1952) Gesteine und tekztonik im ostabschnitt der nordalpinen grauwackenzone vom Alpen-Ostrand bis zum Aflenzer Becken. Mitt Geol Gesell 42:1-234

Cornelius HP (1953) Grundzüge der allgemeinen Geologie. Springer, Wien

Cornelius HP, Clar E (1939) Geologie des Großglocknergebietes. Teil 1 Abh Reichst f Bodenf Zweigst. Wien 25:1-306

Cornelius HP, Cornelius-Furlani M (1925) Bericht über geologischen Untersuchungen an der insubrischen Linie im unteren Veltlin. Anz Österr Akad Wiss math nat Kl 62:209-211

Haberfelner E (1935) Die geologie des Eisenerzer Reichenstein und des Polster. Mitt Abt Bergbau usw Joanneum 2:3-32

Handy MR (1996) The transition from passive to active margin tectonics: a case study from the zone of Samedan (eastern Switzerland). Int J Earthsci Geol Rundsch 85:832-851

Handy MR, Herwegh M, Regli C (1993) Tektonische entwicklung der westlichen Zone von Samedan (oberhalbstein, Graubünden, Schweiz). Eclog Geol Helv 86:785-817
Kühn O (1952) Hans Peter Cornelius-ein Leben für die Alpen. Mitt Geol Ges Wien 42-43:251-262

Nievoll J (1984) Der Südrand der Grauwackenzone zwischen Stübming und Neuberg (Obersteiermark, ÖK 103 Kindberg). Mitt Österr Geol Ges 77:63-71

Prey S (1978) Rekonstruktionsversuch der alpidischen Entwicklung der Ostalpen Mitt österr geol Ges 69:1-25

Rössli F (1944) Fazielle und tektonische Zusammenhänge zwischen Oberengadin und Mittelbünden. Eclog Geol Helv 37:354-383

Spengler E (1921) Zur Tektonik des obersteirischen Karbonzuges bei Thörl und Turnau. Jb Geol SA 70:235-254

Tollmann A (1973) Grundprinzipien der alpinen Deckentektonik. Eine Systemanalyse am Beispiel der Nördlichen Kalkalpen. Deuticke, Wien

von Gärtner HR (1934) Die Eingliederung des ostalpinen Paläozoikums. ZDDG 86:241-265 